\title{
Academic Technology Experience and Preference on Online Learning in Indonesian Higher Education Institutions: Students' Perspectives
}

\author{
Ryani Yulian ${ }^{1 *}$, Ufi Ruhama ${ }^{2}$ iD \\ 1,2 Department of Management, Universitas Muhammadiyah Pontianak, Indonesia \\ *Corresponding author: ryani.yulian@unmuhpnk.ac.id
}

\begin{abstract}
Amidst the Covid-19 Pandemic, most higher education institutions have shifted to online learning to sustain the existence of the universities. However, the readiness and effectiveness of private higher education institutions in Indonesia, especially in Kalimantan, are still questionable. This study focused on analysing and understanding the academic technology experience and preference for online learning in Indonesian higher education institutions from the students' perspectives. A survey of 302 respondents from private higher education institutions was corroborated with semi-structured interviews. The results indicated that the majority of the respondents have limited access to technology devices and ownership. Most of them need academic features integrated into the learning management system for their successful study. The majority of the respondents preferred to have a face-to-face class, but they are receptive to online learning. However, they need to get situated in academic situations that facilitate their technology literacies and skills. In addition, the institutions and lecturers should go in the same direction. Therefore, the data sources can contribute meaningful insights for policy-makers to design accessible and adaptive online learning for the students.
\end{abstract}

Keywords: Technology, Experience, Preference, Online Learning, Students' Perspective

$\begin{array}{ll}\text { History: } & \\ \text { Received } & \text { : August 08, } 2021 \\ \text { Revised } & \text { : August 10, } 2021 \\ \text { Accepted } & \text { : September 26, } 2021 \\ \text { Published } & \text { : October 25, } 2021\end{array}$

\section{INTRODUCTION}

Tremendous changes in the educational field have shifted the education paradigm, particularly online learning at Indonesian higher education due to the Covid-19 Pandemic (Dewantara \& Nurgiansah, 2020; Dhawan, 2020; Yulia, 2020). Online learning has penetrated higher education institutions with the continuous integrated program and widespread method of providing education (Bali \& Liu, 2018; Wallace, 2010). The unforeseen transformation from offline learning to online learning may confound the hindrances in the global context and obstacles in terms of access to education (Hadjeris, 2021; Nugroho et al., 2021). Higher education institutions in Indonesia have to deal with the changing practice of teaching and learning due to the closure of offline activities (Hwang et al., 2021; Satyawan et al., 2021). Numerous universities must confront the adjustments of their teaching and learning activity to enable the sustainability of the universities (Saha et al., 2021; Sujarwo et al., 2020). The use of information and communication technology as the platform of online earning is unavoidable (Li et al., 2018; Lynch et al., 2021).

However, the utilization of this technology encounters some hindrances. One of the obstacles is the readiness of the lecturers, students, and infrastructures to cope with online learning (Arizona et al., 2020; Hutauruk \& Sidabutar, 2020; Windhiyana, 2020). A distinctive circumstance of private higher institutions in West Kalimantan, Indonesia, is that the majority of the students come from remote areas. Therefore, private higher education institutions should be adapted to remote learning amid the Covid-19 Pandemic. Private higher educations 
in West Kalimantan should map a benchmark for the utilization of online learning in the learning management system. It is crucial to maintain the livelihood of online learning for many years to come as the effect of hybrid learning will extend to live in the educational setting.

Online education has become prevalent and pervasive in higher education, where teaching has no longer boundaries and is not isolated in a face-to-face learning activity in the classroom (Albashtawi \& Al Bataineh, 2020; Bahasoan et al., 2020; Hwang et al., 2021). The practice of online education has been investigated for many years, and the outcome can be effective by deliberate instructional design and a well-planned system. Amidst the Covid-19 Pandemic, online learning has become very popular as the platform of teaching and learning activity in higher education institutions; it experienced dramatic conditions because of the integration of digital technology (Alhazzani, 2020; Shea et al., 2013). It is crucial to choose and utilize the best and proper online learning based on characteristics, needs, and conditions (Sujarwo et al., 2020; Tang et al., 2021).

As a result, adopting a conducive online learning experience should not be considered as a technical issue but also a pedagogical paradigm for better implementation of online learning in higher education institutions (Ali, 2020; Rafique et al., 2021). Online learning has some benefits for both learners and teachers. It can foster learning experiences for the students by interacting, collaborating, and transforming learning with the immersion of various technological tools (Ali, 2020; Schmitz et al., 2021). Afterward, the proliferation of technology has provided multiple ways for teaching and learning environments, such as synchronous and asynchronous learning. Both the teachers and the students can choose the real-time delivery method with non-face-to-face learning (Glassman et al., 2021; Jamalpur et al., 2021; Simamora, 2020). The method delivery should be based on the emerging situations so that teaching and learning processes can be meaningful activities.

The implication of online learning for remote learning plays a significant role in online learning success for higher education institutions. Higher education institutions, especially in developing countries, must adapt online education appropriately based on the students' needs and level of expertise (Lapitan et al., 2021; Yilmaz \& Korur, 2021). Online learning development in Indonesia needs extra efforts to strengthen the application in higher education institutions since the rise of online learning has just begun in the past two years as the impact of the Covid-19 Pandemic (Anugrahana, 2020; Malyana, 2020). Online education needs have been overgrown to ensure accessibility and affordability for higher education institutions (Janse van Rensburg, 2018; Maqableh \& Alia, 2021).

Research trends on distance education for remote learning proved that online learning in today's era must apply consolidation between higher education institutions with remote learning and instructional design to ensure the quality assurance of online learning (ZawackiRichter \& Naidu, 2016). However, online learning may cause some problems for remote learning. Online education faces some technical issues, such as poor internet connectivity in some marginalized areas, that can hamper the application of effective online learning (AlAmin et al., 2021; Wu \& Cheng, 2019). This condition should be taken into account by private higher education institutions so that the implementation of online learning can run effectively. They must concern about the preparation to deal with the support of enhancing and utilizing plenty of online activities and assessment forms to provide meaningful learning for the students in terms of affordable technology, resource accessibility, and flexibility (A1Amin et al., 2021; Tseng et al., 2019).

This study aimed to discover students' perspectives on online learning of private universities and its implication to remote learning based on the applicability of online learning for long-term application. Students' perspectives on online learning are expected to contribute inputs and feedback for the policy-maker at the higher education institutions to 
meet the need for online learning with remote learning. Students' perspectives can be considered an essential contributing factor for online learning since they can exhibit firsthand insights into their learning experiences (Dawson et al., 2019; Van Wart et al., 2020).

Their perspectives can also yield more precise insights and detailed pictures of students' experiences in the online learning environment (Amstrong, 2011; Sujarwo et al., 2020). In today's educational setting, online learning provides ample access for students. However, their perspective and beliefs should be worth considering because their views can change over time with the continuous implementation of online learning, especially when they show inconvenience and confusion (Nikdel Teymori \& Fardin, 2020). Students' data on online learning can contribute to decisions for the suitable instructional process when higher education institutions implement the practice of online learning continuously (OwusuFordjour et al., 2020; Usher et al., 2021). The analysis of students' perspectives explored students' information technology on online learning, especially on device, ownership, access, and use, campus technology experiences, academy technology preferences, experiences, and learning. Therefore, this study aimed to examine students' experiences and preferences on online learning based on the empirical experiences to posit articulated data on the application of online learning for better implementation of online learning in the future.

\section{METHODS}

This study was based on a survey of students' beliefs in online learning. The study employed a probability sample with simple random sampling that occupies indiscriminately from the broad population from private universities and has an equal chance of being selected to generalize (Cohen, L., Manion, L., \& Marrison, 2018). The sample consisted of 302 respondents. The research instruments corresponding to the data gathering process consist of questionnaires and semi-structured interviews. The questionnaires were given first hand and proceeded in a semi-structured interview. The questionnaires were adapted from the ECAR Study of Undergraduate and Information Technology, 2018. The questionnaires explored the technology ownership from the students, the use pattern of technology, and students' expectations based on the students' experiences on online learning. The second research instrument was a semi-structured interview. There were 25 respondents voluntarily involved in the interviews as data sources. The 25 data sources can investigate more profound ideas, especially on a single case, to achieve the saturation level (Charles et al., 2015).

\section{RESULTS AND DISCUSSION}

\section{Results}

The demographic variables of this study consist of age, gender, types of higher education institutions, and residence. There were more students with ages ranging between 18-19 years old (65.2\%) from 302 respondents and ages above 20 years old (34.8\%). It implicated that the majority of the students firstly experienced online learning when entering higher education institutions. There were more female respondents (66.2\%) than male respondents $(33.8 \%)$. The majority of the students come from the academic higher institution or university $(57.6 \%)$, vocational higher institution or polytechnic $(41.4 \%)$, and college $(1 \%)$. Most of them reside in rural areas $(80.3 \%)$, while the rest reside in urban areas $(19.7 \%)$. The initial question asked the students about students' devices, accessibility, and ownership of devices regarding Internet-capable devices such as desktops, laptops, tablets, smartphones, wearables, gaming devices, and streaming media devices. The majority of devices ownership was one device $(61.3 \%)$, two devices $(26.5 \%)$, three devices $(6.3 \%)$, four devices $(2.3 \%)$, and five devices and more (2.6\%). In terms of accessibility of devices, most students have access 
to smartphones (94.4\%) and laptops $(65.5 \%)$. Only a few have access to the personal computer $(5.6 \%)$, tablet and smartwatch consecutively (4.3\%).

Some empirical studies have proven that students' technology ownership and accessibility play an essential role in students' learning. The students' devices such as smartphones and laptops incorporated for students' daily learning can encourage a productive and good learning environment to accelerate students' skills and abilities. However, the accessibility and use of technology devices for learning must be synergized by the demand of today's technology of the changing method in education, especially where there are some hindrances such as lack of technology literacy and lack of confidence (Saini \& Salim AlMamri, 2019). Some students from rural areas may find it challenging to utilize technologies without the support of the institutions. Apart from asking the students' accessibility to devices, they were also asked to clarify how they have access to the devices in terms of ownership. The majority of the students have access to smartphones as they own them (95.6\%), but some also borrow from family and friends $(3.4 \%)$. The students personally own laptops (63.7\%) and borrow from family or friends $(32.5 \%)$. A small proportion of students have access to the devices provided by the university or college, e.g., smartphones $(1 \%)$ and laptops (3.8\%).

This section asks about students' experiences with technology that they use at their college/university and with technology provided for them at the institution. They were asked to describe their overall technology experiences at the institutions. The majority of the respondents opined neutral response on the overall technology experiences $(30,8 \%)$, and experiences with internet connection at campus residences are fair (39.45). But some opinions implicated the overall technology experiences are poor (20.8\%), and the experiences with internet connection at campus residences are poor $(24.2 \%)$. When the students asked about their experiences of delivery methods in a competency-based program, most of them said that all of the courses had been completed online in the past 12 months during Covid-19 Pandemic (74.5\%). Some of the courses were delivered completely online $(23.5 \%)$. None of the courses was delivered completely online (2\%).

To examine more ideas about the students' campus technology experiences, they were asked to opine to the best of their knowledge of their institution's online student success tools. The online tool on guidance about courses in the future is the primary choice of the students $(60.9 \%)$, tools that suggest how to improve performance in a course $(48 \%)$, and tools that explain degree planning or mapping, especially to identify courses to complete the degree in the university (28.5). It is related to the existing knowledge of previous studies that online student success tools must be designed by critical dimension; two of them are educational system quality content and information quality (Efiloğlu Kurt, 2018; Mehrolia et al., 2021; Wang \& Wang, 2009). The educational system can be indicated from features of the learning management system in the needs and appropriateness, for the students, and quality content and information quality refer to the usefulness of online success tools for the students (Mehrolia et al., 2021).

Consecutively, after the students were asked to choose their favourable and valuable online tools for their study, they were also asked to opine about the usefulness of the online student success tools provided by the institutions. The majority of them said that early-alert systems designed to catch potential academic trouble are beneficial $(49.7 \%)$. They agreed that tools that suggest improving performance in a course are helpful (45.4\%). They also said tools that offer new or different academic resources are helpful (44.3\%), and self-service tools for conducting student-related business (e.g., registration, finances, grades, and transcripts) are useful (44.3\%). Attributes for the usefulness of online success tools for the students indicated that students need the learning management system that organizes and 
provides access to their learning, such as learning database, syllabus, lesson plan, and tracking academic progress (Aldiab et al., 2019).

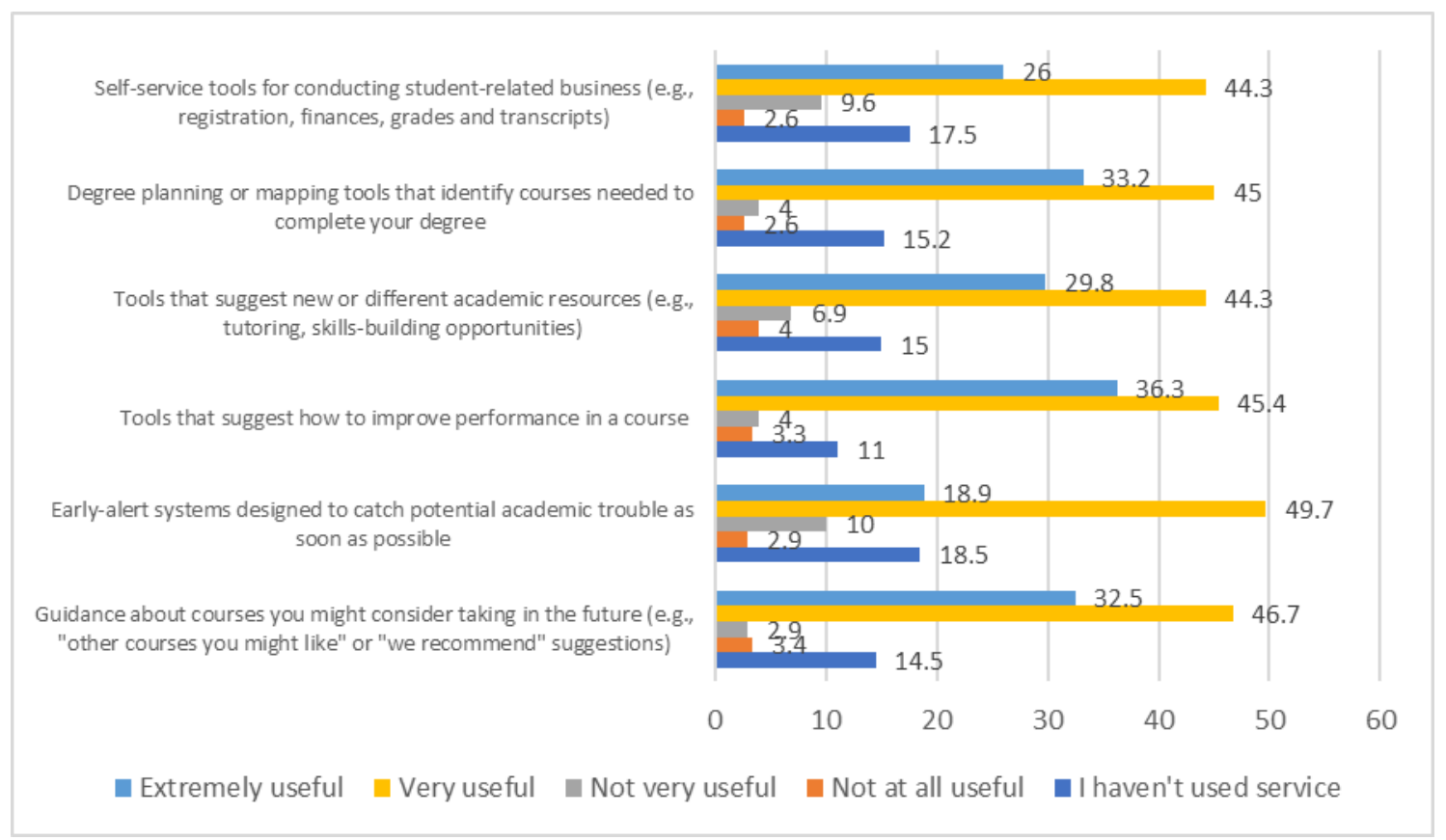

Figure 1. The usefulness of online student success tools

In terms of the learning management system used in online learning, the students were asked about their experiences in the past 12 months, primarily how much they used the institution's learning management system (e.g., Google Classroom, Edmodo, and Moodle). The majority of them used Google Classroom, Edmodo, and Moodle for all the courses $(67.4 \%)$ and used it for most of their courses (30.6\%). It is essential to ask the students to posit some ideas about the learning management system since LMS is the most widely used and available educational technology for students in all levels of education (Galanek et al., 2018). There are still some courses that do not utilize learning management systems, such as Google Classroom, Edmodo, and Moodle for online learning. It is worth considering for the institutions to use a friendly learning management system that provides online platforms with management, monitoring, scheduling, learning, and assessing the course (Cavus, 2015). Institutions must consider using LMS that assists enhancement, efficiency, flexibility, and power to the educational process, especially to the students' performance and students' outcomes (Aldiab et al., 2019). Private universities in developing countries can take advantage of the current technological developments for learning management systems by considering the organized courses and continuous implementation of online learning. But they must ensure the use of LMS will provide suitability and easiness for the students to use the interface from the mobile device with stable and accessible Internet connection (Dobre, 2015).

When the students were asked about their satisfaction in using the learning management systems for online learning, most respondents are neutral $(53.3 \%)$ and satisfied (38.2\%). The proportion of neutral statements (52.3\%) implied that students hesitated their satisfactory level using the learning management systems for the courses. For the campus technology experience variable, the students were also inquired to opine on difficulties in terms of physical or learning disability that requires accessible or adaptive technologies for their coursework. The majority of them revealed that they do not have a physical or learning 
disability that needs accessible or adaptive technologies for helping them in the coursework (72.2\%). Still, they are several of them who have one or more learning disabilities $(13.9 \%)$.

In terms of campus technology experiences, the students were asked to unveil the institution's awareness of student needs for the accessible or adaptive technologies needed for the coursework. Most of them stated that institutions' awareness of student needs for accessible or adaptive technologies necessary for the coursework is fair (44.7\%), but some statements revealed the institutions are not aware of the conditions for accessible or adaptive technologies (8.3\%). Campus technology experiences can contribute to academic performance and the outcome of learning.

In addition to unveiling the support from the campus on online learning, the students would also rate the institution's support for the accessible or adaptive technologies needed for the coursework. The institution's support for the accessible or adaptive technologies necessary for the coursework is fair (37.5\%). However, some proportions of students' opinions revealed the institution's support for the accessible or adaptive technologies necessary for the coursework is poor $(26.1 \%)$. Interestingly, students are still not yet provided with the accessible or adaptive technologies as needed $(6 \%)$. One primary consideration from the institutions to provide support for accessible or adaptive technologies is to provide universal design to develop online course processes. They must give cultural encouragement for online learning (Van Rooij \& Zirkle, 2016).

In this section, we asked how technology was used at the institution to support student learning and about the students' opinions of that technology. The students were asked to respond in what type of learning environment they most preferred to learn. Most of them preferred to learn in one that is completely face-to-face $(42.1 \%)$. Some of them preferred to learn in the situation with half online and half face-to-face $(31.8 \%)$, but only several of them preferred to learn in one that is completely online $(4 \%)$.

Regarding the preferences in the learning environment, students also posited ideas in a typical day, approximately the time they spent actively engaged in each of the following online activities. The majority of them spent 1-2 hours in social media such as Facebook, Instagram, Twitter, TikTok (43\%), 1-2 hours in streaming video (32.1\%), and other online activity $(29.1 \%)$. It replicated previous studies that the majority of the students used prolonged engagement of social media for non-academic purposes (Kolhar et al., 2021). Facebook as a social networking site exposes a medium platform outside the traditional classroom, but it cannot be considered an educational platform for building interactions with teachers (Manu et al., 2021).

Furthermore, the students were asked to think about their university/ college experiences within the past 12 months and rate the level of agreement with the following statements. The majority of the students agreed that the lecturers typically utilize technology to engage the students in the learning process (45.4\%). They also agreed that the lecturers utilize technology to enhance learning with additional materials (49.3\%). Most of them also opined that the lecturers motivate them to use their own technology devices during class (44.7\%). The lecturers encourage the students to use online collaboration tools to collaborate with the instructor or other students (44\%). Interestingly, the lecturers motivate the students to use technology for creative or critical-thinking tasks (49.7\%). Finally, the lecturers have the students use their laptops as a learning tool in class $(43.3 \%)$.

The students also posited some ideas when thinking about the future, especially to the extent they agreed how technology contributes to their learning skills for the future. The majority strongly agreed that technology would play an essential role in their career $(39.7 \%)$. Some of them were neutral that technologies used in the course are relevant to their job (38.7\%). Some also agreed that their technical skills in the courses would adequately prepare them for their careers (42\%). The institutions and the lecturers must foster technology-related 
knowledge and digital skills to the students, but they cannot merely use the technology as a tool system; they must direct new technology as a set of resources to reshape their institutions' education goals (Burbules et al., 2020).

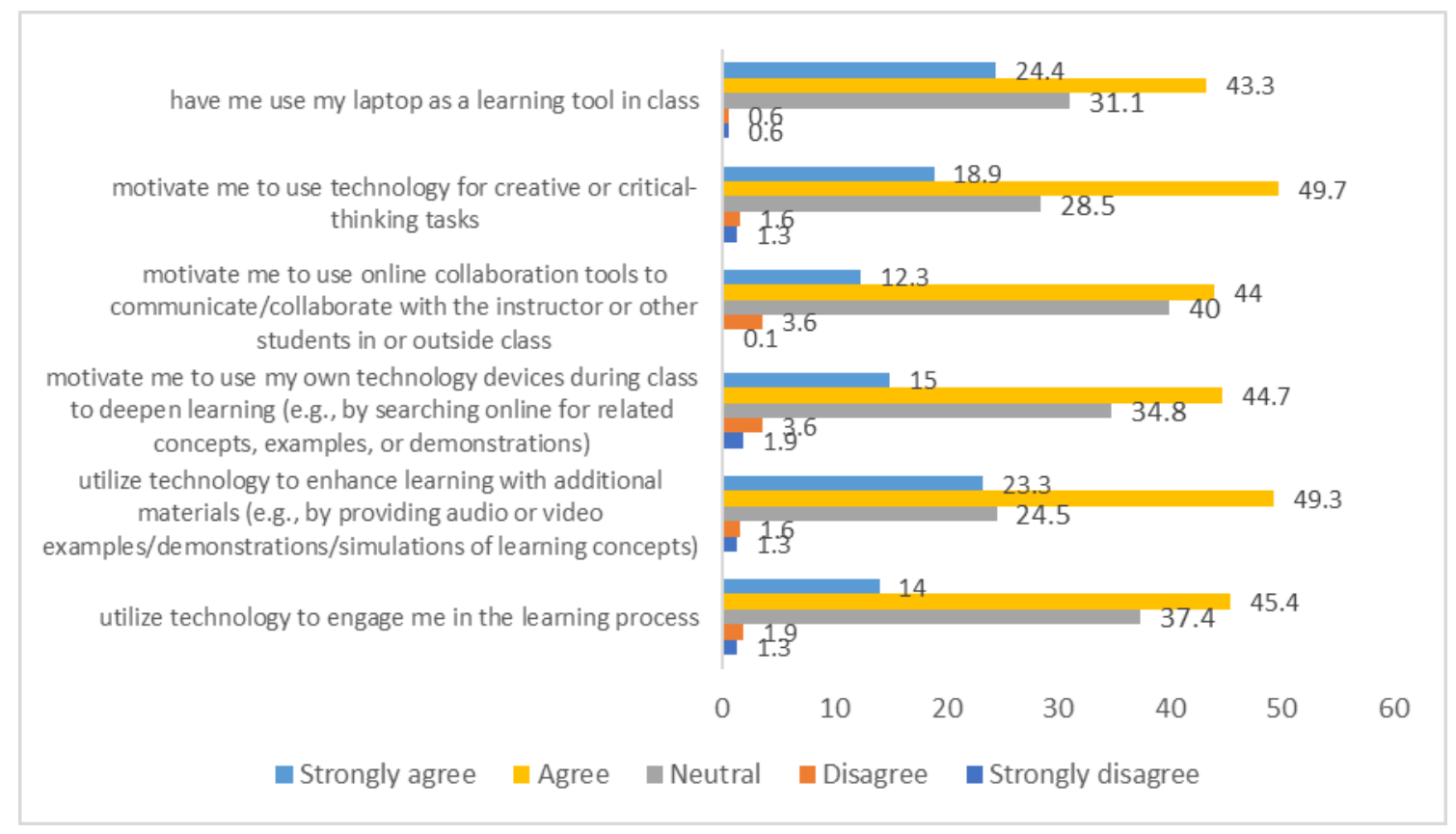

Figure 3. The extent lecturers use the technology

To corroborate the questionnaires in terms of expected measures from lecturers and institutions with technology to increase academic success, 25 respondents participated in semi-structured interviews. They were interviewed based on the volunteer willingness, and their identities are anonymous. The first question asked the students' expectations from the lecturers with technology to foster their academic success. Based on the thematic analysis, the final theme obtained from the coding led to the two main themes of the students' expectation of their lecturers' technology aspect such as the method of delivery and lecturers' technology literacy. The second question asked students' expectations from the universities with technology to foster their academic success, which covers three primary themes: provision of technology literacy, features of learning management system, and accessibility to technology and devices.

\section{Discussion}

Early studies have provided some fundamental insights on the method of delivery in online learning. Method of delivery should fulfil students' needs in online learning, particularly synchronous teaching. The students will have social support, task planning, task negotiation, and a lively learning environment (Rinekso \& Muslim, 2020). They are not merely isolated in one-way direction of teaching. In terms of the role of technology from universities for students' academic success, universities must have capacity building to foster both the lecturers and students with technology literacy and technical proficiency on online learning and learning management systems (Mpungose, 2020; Muthuprasad et al., 2021).

It is helpful to provide university-wide access to learning pedagogy as a major factor determining online learning success (Nugroho et al., 2021). The availability of learning management systems with leveraging technological features can enhance the learning experience for the students (Mtebe, 2015; Nambiar, 2020). Accessibility to technology and devices also plays a significant role in the effectiveness of online learning. Students with 
good access to technology and devices perceive online learning more effectively and stimulate them in the learning process (Butnaru et al., 2021).

The data can contribute to the lecturers' effort to improve their technical skills to the best performance of online learning. The lecturers should use technology effectively, upgrade their technology literacy and skills, and encourage the students in online collaboration mediated by creative and critical-thinking activity. Some students also revealed that the technological skills integrated into the courses would be adequately relevant and supportive for their career, but they expect support on technology literacy. Therefore, all these attributes contribute to raising the universities awareness of the students' needs for accessible or adaptive technologies needed for the coursework. From the research findings, the applicable online learning model should combine synchronous activity with the asynchronous activity that enables the students to experience social interaction with the lecturers, materials, and peers. This study is limited to analysing the academic technology experience and preference for online learning in private universities. Further studies can cope with the investigation of educational technology experiences from lecturers' and policy-makers perspectives and triangulate with content analysis on the university's use of learning management systems.

\section{CONCLUSION}

The findings of the study demonstrated that the majority of the students reside in rural areas with limited access and ownership to devices. Their overall experiences on online learning are fair, but some are also poor, especially with internet connection at campus residences. Both situations are intriguing because the experiences are also the problems when implementing online learning. Most of the students also responded neutrally about their satisfaction with using the learning management system in the universities. In terms of students' preferences on online learning, most of them preferred to learn in one that is entirely face-to-face. Still, some are also open to the implementation of online learning.

\section{REFERENCES}

Al-Amin, M., Zubayer, A. Al, Deb, B., \& Hasan, M. (2021). Status of tertiary level online class in Bangladesh: students' response on preparedness, participation and classroom activities. Heliyon, 7(1), e05943. https://doi.org/10.1016/j.heliyon.2021.e05943.

Albashtawi, A. H., \& Al Bataineh, K. B. (2020). The effectiveness of google classroom among EFL students in Jordan: An innovative teaching and learning online platform. International Journal of Emerging Technologies in Learning, 15(11), 78-88. https://doi.org/10.3991/ijet.v15i11.12865.

Aldiab, A., Chowdhury, H., Kootsookos, A., Alam, F., \& Allhibi, H. (2019). Utilization of Learning Management Systems (LMSs) in higher education system: A case review for Saudi Arabia. Energy Procedia, 160(2018), 731-737. https://doi.org/10.1016/j.egypro.2019.02.186.

Alhazzani, N. (2020). MOOC's impact on higher education. Social Sciences \& Humanities Open, 2(1), 100030. https://doi.org/10.1016/j.ssaho.2020.100030.

Ali, W. (2020). Online and Remote Learning in Higher Education Institutes: A Necessity in light of COVID-19 Pandemic. Higher Education Studies, 10(3), 16-25. https://doi.org/10.5539/hes.v10n3p16.

Amstrong, D. (2011). Students' Perceptions of Online Learning and Instructional Tools: A Qualitative Study of Undergraduate Students Use of Online Tools. TOJET: The Turkish Online Journal of Educational Technology, 10(3), 222-226. https://files.eric.ed.gov/fulltext/ej944973.pdf. 
Anugrahana, A. (2020). Hambatan, Solusi dan Harapan : Pembelajaran Daring Selama Masa Pandemi Covid-19 Oleh Guru Sekolah Dasar. Scholaria: Jurnal Pendidikan Dan Kebudayaan, 10(3), 282-289. https://doi.org/10.24246/j.js.2020.v10.i3.p282-289.

Arizona, K., Abidin, Z., \& Rumansyah, R. (2020). Pembelajaran Online Berbasis Proyek Salah Satu Solusi Kegiatan Belajar Mengajar Di Tengah Pandemi Covid-19. Jurnal Ilmiah Profesi Pendidikan, 5(1). https://doi.org/10.29303/jipp.v5i1.111.

Bahasoan, A., Ayuandiani, W., Mukhram, M., \& Rahmat, A. (2020). Effectiveness of Online Learning In Pandemic Covid-19. Jurnal Kajian Pendidikan Dan Hasil Penelitian, 6(3), 100-106. https://doi.org/10.46729/ijstm.v1i2.30.

Bali, S., \& Liu, M. C. (2018). Students' perceptions toward online learning and face-to-face learning courses. Journal of Physics: Conference Series, 1108(1). https://doi.org/10.1088/1742-6596/1108/1/012094.

Burbules, N. C., Fan, G., \& Repp, P. (2020). Five trends of education and technology in a sustainable future. Geography and Sustainability, 1(2), 93-97. https://doi.org/10.1016/j.geosus.2020.05.001.

Butnaru, G. I., Niţă, V., Anichiti, A., \& Brînză, G. (2021). The effectiveness of online education during covid 19 pandemic - a comparative analysis between the perceptions of academic students and high school students from romania. Sustainability (Switzerland), 13(9). https://doi.org/10.3390/su13095311.

Cavus, N. (2015). Distance Learning And Learning Management Systems. Procedia-Social and Behavioral Sciences, 191, 872-877. https://doi.org/10.1016/j.sbspro.2015.04.611.

Charles, S. J., Ploeg, C., \& Mckibbon, J. A. (2015). Sampling in Qualitative Research: Insights from an Overview of the Methods Literature. The Qualitative Report, 20(11), 1772. https://doi.org/10.46743/2160-3715/2015.2373.

Cohen, L., Manion, L., \& Marrison, K. (2018). Research Methods in Education (Eigth Edit). Routledge, Taylor and Francis Group.

Dawson, P., Henderson, M., Mahoney, P., Phillips, M., Ryan, T., Boud, D., \& Molloy, E. (2019). What makes for effective feedback: staff and student perspectives. Assessment \& Evaluation in Higher Education, 44(1), 25-36. https://doi.org/10.1080/02602938.2018.1467877.

Dewantara, J. A., \& Nurgiansah, T. H. (2020). Efektivitas Pembelajaran Daring di Masa Pandemi COVID 19 Bagi Mahasiswa Universitas PGRI Yogyakarta. Jurnal Basicedu, 5(1), 367-375. https://doi.org/10.31004/basicedu.v5i1.669.

Dhawan, S. (2020). Online Learning: A Panacea in the Time of COVID-19 Crisis. Journal of Educational Technology 5ystems, 49(1), 5-22. https://doi.org/10.1177/0047239520934018.

Dobre, I. (2015). Learning Management Systems for Higher Education - An Overview of Available Options for Higher Education Organizations. Procedia - Social and Behavioral Sciences, 180(November 2014), 313-320. https://doi.org/10.1016/j.sbspro.2015.02.122.

Efiloğlu Kurt, Ö. (2018). Examining an e-learning system through the lens of the information systems success model: Empirical evidence from Italy. Education and Information Technologies 2018 24:2, 24(2), 1173-1184. https://doi.org/10.1007/S10639-0189821-4.

Galanek, J. D., Gierdowski, D. C., \& Brooks, D. C. (2018). ECAR Study of Undergraduate Students and Information. Educause Center for Analysis and Research, 49.

Glassman, M., Kuznetcova, I., Peri, J., \& Kim, Y. (2021). Cohesion, collaboration and the struggle of creating online learning communities: Development and validation of an online collective efficacy scale. Computers and Education Open, 2(January), 100031. https://doi.org/10.1016/j.caeo.2021.100031. 
Hadjeris, F. (2021). Revisiting sustainable development Goal 4 in the context of COVID-19 Pandemic: A case study of online teaching in Algerian higher education institutions. Human Behavior and Emerging Technologies, 3(1), 160-168. https://doi.org/10.1002/hbe2.245.

Hsu, M. K., Wang, S. W., \& Chiu, K. K. (2009). Computer attitude, statistics anxiety and self-efficacy on statistical software adoption behavior: An empirical study of online MBA learners. Computers in Human Behavior, 25(2), 412-420. https://doi.org/10.1016/j.chb.2008.10.003.

Hutauruk, A., \& Sidabutar, R. (2020). Kendala pembelajaran daring selama masa pandemi di kalangan mahasiswa pendidikan matematika: Kajian kualiatatif deskriptif. Journal of Mathematics Education and Applied, 02(01), 45-51. https://doi.org/10.36655/sepren.v2i1.364.

Hwang, G.-J., Wang, S.-Y., \& Lai, C.-L. (2021). Effects of a social regulation-based online learning framework on students' learning achievements and behaviors in $\begin{array}{llll}\text { mathematics. } & \text { Computers } & \text { E } & \end{array}$ https://doi.org/10.1016/j.compedu.2020.104031.

Jamalpur, B., Kafila, Chythanya, K. R., \& Kumar, K. S. (2021). A comprehensive overview of online education - Impact on engineering students during COVID-19. Materials Today: Proceedings. https://doi.org/10.1016/j.matpr.2021.01.749.

Janse van Rensburg, E. S. (2018). Effective online teaching and learning practices for undergraduate health sciences students: An integrative review. In International Journal of Africa Nursing Sciences (Vol. 9, pp. 73-80). Elsevier Ltd. https://doi.org/10.1016/j.ijans.2018.08.004.

Kolhar, M., Kazi, R. N. A., \& Alameen, A. (2021). Effect of social media use on learning, social interactions, and sleep duration among university students. Saudi Journal of Biological Sciences, 28(4), 2216-2222. https://doi.org/10.1016/j.sjbs.2021.01.010.

Lapitan, L. D., Tiangco, C. E., Sumalinog, D. A. G., Sabarillo, N. S., \& Diaz, J. M. (2021). An effective blended online teaching and learning strategy during the COVID-19 pandemic. Education for Chemical Engineers, 35(May 2020), 116-131. https://doi.org/10.1016/j.ece.2021.01.012.

Li, J., Zhang, X., \& Hu, Z. (2018). The design and application of flip classroom teaching based on computer technology. International Journal of Emerging Technologies in Learning, 13(10), 95-107. https://doi.org/10.3991/ijet.v13i10.9453.

Lynch, M., Sage, T., Hitchcock, L. I., \& Sage, M. (2021). A heutagogical approach for the assessment of Internet Communication Technology (ICT) assignments in higher education. International Journal of Educational Technology in Higher Education, 18(1). https://doi.org/10.1186/s41239-021-00290-X.

Malyana, A. (2020). Pelaksanaan Pembelajaran Daring Dan Luring Dengan Metode Bimbingan Berkelanjutan Pada Guru Sekolah Dasar Di Teluk Betung Utara Bandar Lampung. Pedagogia: Jurnal Ilmiah Pendidikan Dasar Indonesia, 2(1), 67-76. https://doi.org/10.52217/pedagogia.v2i1.640.

Manu, B. D., Ying, F., Oduro, D., \& Boateng, S. A. (2021). Student engagement and social media in tertiary education: The perception and experience from the Ghanaian public university. Social Sciences \& Humanities Open, 3(1), 100100. https://doi.org/10.1016/j.ssaho.2020.100100.

Maqableh, M., \& Alia, M. (2021). Evaluation online learning of undergraduate students under lockdown amidst COVID-19 Pandemic: The online learning experience and students' satisfaction. Children and Youth Services Review, 128(1). https://doi.org/10.1016/j.childyouth.2021.106160.

Mehrolia, S., Alagarsamy, S., \& Indhu Sabari, M. (2021). Moderating effects of academic 
involvement in web-based learning management system success: A multigroup analysis. Heliyon, 7(5), e07000. https://doi.org/10.1016/j.heliyon.2021.e07000.

Mpungose, C. B. (2020). Emergent transition from face-to-face to online learning in a South African University in the context of the Coronavirus pandemic. Humanities and Social Sciences Communications 2020 7:1, 7(1), 1-9. https://doi.org/10.1057/s41599020-00603-X.

Mtebe, J. S. (2015). Learning Management System success: Increasing Learning Management System usage in higher education in sub-Saharan Africa. International Journal of Education and Development Using Information and Communication Technology, 11(2), 51-64. https://files.eric.ed.gov/fulltext/EJ1074158.pdf.

Muthuprasad, T., Aiswarya, S., Aditya, K. S., \& Jha, G. K. (2021). Students' perception and preference for online education in India during COVID -19 pandemic. Social Sciences \& Humanities Open, 3(1). https://doi.org/10.1016/j.ssaho.2020.100101.

Nambiar, D. (2020). The impact of online learning during COVID-19: students ' and teachers' perspective. The International Journal of Indian Psychology, 8(2), 783793. https://doi.org/10.25215/0802.094.

Nikdel Teymori, A., \& Fardin, M. A. (2020). COVID-19 and Educational Challenges: A Review of the Benefits of Online Education. Annals of Military and Health Sciences Research, 18(3). https://doi.org/10.5812/amh.105778.

Nugroho, A., Ilmiani, D., \& Rekha, A. (2021). EFL Teachers' Challenges and Insights of Online Teaching amidst Global Pandemic. Metathesis: Journal of English Language, Literature, and Teaching, 4(3), 277. https://doi.org/10.31002/metathesis.v4i3.3195.

Owusu-Fordjour, C., Koomson, C. K., \& Hanson, D. (2020). The Impact of Covid-19 on Learning-The Perspective of the Ghanaian Student. European Journal of Education Studies, 7(3), 88-101. https://doi.org/10.5281/zenodo.3753586.

Rafique, G. M., Mahmood, K., Warraich, N. F., \& Rehman, S. U. (2021). Readiness for Online Learning during COVID-19 pandemic: A survey of Pakistani LIS students. The Journal of Academic Librarianship, 47(3), 102346. https://doi.org/10.1016/j.acalib.2021.102346.

Rinekso, A. B., \& Muslim, A. B. (2020). Synchronous online discussion: Teaching English in higher education amidst the covid-19 pandemic. 5(2), 155-162. https://doi.org/10.21070/jees.v5i2.646.

Saha, A., Dutta, A., \& Sifat, R. I. (2021). The mental impact of digital divide due to COVID19 pandemic induced emergency online learning at undergraduate level: Evidence from undergraduate students from Dhaka City. Journal of Affective Disorders, 294(June), 170-179. https://doi.org/10.1016/j.jad.2021.07.045.

Saini, D. K., \& Salim Al-Mamri, M. R. (2019). Investigation of Technological Tools used in Education System in Oman. Social Sciences \& Humanities Open, 1(1), 100003. https://doi.org/10.1016/J.SSAHO.2019.100003.

Satyawan, I. M., Wahjoedi, W., \& Swadesi, I. K. I. (2021). The Effectiveness of Online Learning Through Undiksha E-Learning During the Covid-19 Pandemic. Journal Education Technology, 5(2). https://doi.org/10.23887/jet.v5i2.32364.

Schmitz, S. M., Schipper, S., \& Lemos, M. (2021). Development of a tailor-made surgical online learning platform, ensuring surgical education in times of the COVID19 pandemic https://doi.org/. BMC Surg 21, 196. https://doi.org/10.1186/s12893-02101203-5.

Shea, P., Hayes, S., Uzuner Smith, S., Vickers, J., Bidjerano, T., Gozza-Cohen, M., Jian, S. B., Pickett, A. M., Wilde, J., \& Tseng, C. H. (2013). Online learner self-regulation: Learning presence viewed through quantitative content- and social network analysis. International Review of Research in Open and Distance Learning, 14(3), 427-461. 
https://doi.org/10.19173/irrodl.v14i3.1466.

Simamora, R. M. (2020). The Challenges of Online Learning during the COVID-19 Pandemic: An Essay Analysis of Performing Arts Education Students. Studies in Learning and Teaching, 1(2), 86-103. https://doi.org/10.46627/silet.v1i2.38.

Sujarwo, S., Sukmawati, S., Akhiruddin, A., Ridwan, R., \& Suharti Siradjuddin, S. S. (2020). An Analysis of University Students' Perspective On Online Learning in The Midst of Covid-19 Pandemic. Jurnal Pendidikan Dan Pengajaran, 53(2), 125. https://doi.org/10.23887/jpp.v53i2.24964.

Tang, Y. M., Chen, P. C., Law, K. M. Y., Wu, C. H., Lau, Y., Guan, J., He, D., \& Ho, G. T. S. (2021). Comparative analysis of Student's live online learning readiness during the coronavirus (COVID-19) pandemic in the higher education sector. Computers \& Education, 168, 104211. https://doi.org/10.1016/j.compedu.2021.104211.

Tseng, H., Yi, X., \& Yeh, H. T. (2019). Learning-related soft skills among online business students in higher education: Grade level and managerial role differences in selfregulation, motivation, and social skill. Computers in Human Behavior, 95. https://doi.org/10.1016/j.chb.2018.11.035.

Usher, M., Hershkovitz, A., \& Forkosh-Baruch, A. (2021). From data to actions: Instructors' decision making based on learners' data in online emergency remote teaching. British Journal of Educational Technology, 52(4), 1338-1356. https://doi.org/10.1111/BJET.13108.

Van Rooij, S. W., \& Zirkle, K. (2016). Balancing pedagogy, student readiness and accessibility: A case study in collaborative online course development. The Internet and Higher Education, 28, 1-7. https://doi.org/10.1016/J.IHEDUC.2015.08.001.

Van Wart, M., Ni, A., Medina, P., Canelon, J., Kordrostami, M., Zhang, J., \& Liu, Y. (2020). Integrating students' perspectives about online learning: a hierarchy of factors. International Journal of Educational Technology in Higher Education, 17(1), 53. https://doi.org/10.1186/s41239-020-00229-8.

Wallace, R. M. (2010). Online Learning in Higher Education: a review of research on interactions among teachers and students, 3(2), 241-280. https://doi.org/10.1080/14636310303143.

Wang, W. T., \& Wang, C. C. (2009). An empirical study of instructor adoption of web-based learning systems. Computers \& Education, 53(3), 761-774. https://doi.org/10.1016/j.compedu.2009.02.021.

Windhiyana, E. (2020). Dampak Covid-19 Terhadap Kegiatan Pembelajaran Online Di Perguruan Tinggi Kristen Di Indonesia. Perspektif Ilmu Pendidikan, 34(1), 1-8. https://doi.org/10.21009/pip.341.1.

Wu, J. Y., \& Cheng, T. (2019). Who is better adapted in learning online within the personal learning environment? Relating gender differences in cognitive attention networks to digital distraction. Computers and Education, 128. https://doi.org/10.1016/j.compedu.2018.08.016.

Yilmaz, E., \& Korur, F. (2021). The Effects of an Online Teaching Material Integrated Methods on Students' Science Achievement, Attitude and Retention. International Journal of Technology in Education, 4(1). https://doi.org/10.46328/ijte.79.

Yulia. (2020). Online Learning to Prevent the Spread of Pandemic Corona Virus in Indonesia. ETERNAL (English Teaching Journal), 11(1). https://doi.org/10.26877/eternal.v11i1.6068.

Zawacki-Richter, O., \& Naidu, S. (2016). Mapping research trends from 35 years of publications in Distance Education. Distance Education, 37(3), 245-269. https://doi.org/10.1080/01587919.2016.1185079. 